\title{
A novel heterozygous IGF-1 receptor mutation associated with hypoglycemia
}

\author{
R Solomon-Zemler, *, L Basel-Vanagaite ${ }^{1,2,3,4, *}$, D Steier5, S Yakar6, E Mel7, \\ M Phillip ${ }^{1,7}$, L Bazak², D Bercovich ${ }^{8}$, H Werner ${ }^{1,9}$ and L de Vries ${ }^{1,7}$ \\ ${ }^{1}$ Sackler Faculty of Medicine, Tel Aviv University, Tel Aviv, Israel \\ ${ }^{2}$ Raphael Recanati Genetic Institute, Rabin Medical Center - Beilinson Hospital, Petach Tikva, Israel \\ ${ }^{3}$ Felsenstein Medical Research Center, Petach Tikva, Israel \\ ${ }^{4}$ Pediatric Genetics, Schneider Children's Medical Center of Israel, Petach Tikva, Israel \\ ${ }^{5}$ Day Hospitalization Department, Schneider Children's Medical Center of Israel, Petach Tikva, Israel \\ ${ }^{6}$ David B. Kriser Dental Center, Department of Basic Science and Craniofacial Biology, New York \\ University College of Dentistry, New York, New York, USA \\ 7Jesse Z. and Sara Lea Shafer Institute for Endocrinology and Diabetes, Schneider Children's \\ Medical Center of Israel, Petach Tikva, Israel \\ ${ }^{8}$ Tel-Hai College, Tel-Hai, Israel \\ ${ }^{9}$ Shalom and VardaYoran Institute for Human Genome Research, Tel Aviv University, Tel Aviv, Israel \\ *(R Solomon-Zemler and L Basel-Vanagaite contributed equally to this work)
}

\author{
Correspondence \\ should be addressed \\ to $L$ de Vries \\ Email \\ liatdevries@gmail.com
}

\begin{abstract}
Mutation in the insulin-like growth factor-1 receptor (IGF1R) gene is a rare cause for intrauterine and postnatal growth disorders. Patients identified with IGF1R mutations present with either normal or impaired glucose tolerance. None of the cases described so far showed hypoglycemia. We aimed to identify the genetic basis for small for gestational age, short stature and hypoglycemia over three generations in one family. The proband, a 9-year-old male, presented in infancy with recurrent hypoglycemic episodes, symmetric intrauterine growth retardation and postnatal growth retardation. Blood DNA samples from the patient, his parents, a maternal sister and maternal grandmother underwent Sanger sequencing of the IGF1R gene. Primary skin fibroblast cultures of the patient, his mother and age- and sex-matched control donors were used for gene expression and receptor functional analyses. We found a novel heterozygous mutation (c.94+1g>a, D1105E) affecting the splicing site of the IGF1R mRNA in the patient, his mother and his grandmother. Primary fibroblast cultures derived from the patient and his mother showed reduced proliferation and impaired activation of the IGF1R, evident by reduced IGF1R and AKT phosphorylation upon ligand binding. In conclusion, the newly identified heterozygous missense mutation in exon 1 of IGF1R (D1105E) results in impaired IGF1R function and is associated with small for gestational age, microcephaly and abnormal glucose metabolism. Further studies are required to understand the mechanisms by which this mutation leads to hypoglycemia.
\end{abstract}

Key Words
- insulin-like growth factor-1
(IGF-1)
- IGF-1 receptor (IGF1R)
- SGA
- IUGR
- hypoglycemia

Endocrine Connections (2017) 6, 395-403

\section{Introduction}

Growth retardation in children is multifactorial. While most conditions associated with growth impairment are amenable to genetic and molecular analyses, a significant portion of the cases is classified as idiopathic because no specific (genetic or other) defect can be recognized. Growth and developmental conditions under the umbrella of

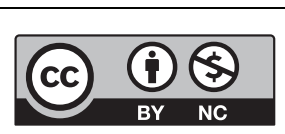

This work is licensed under a Creative Commons Attribution-NonCommercial 4.0 International License. 
congenital insulin-like growth factor-1 (IGF-1) deficiencies include: (i) growth hormone $(\mathrm{GH})$ releasing hormonereceptor $(G H R H-R)$ defect; (ii) $G H$ gene deletion (isolated GH deficiency); (iii) GH receptor $(G H-R)$ gene defects (Laron syndrome); and (iv) IGF1 gene deletion. Additional conditions leading to impairment of the GH-IGF-1 axis are defects of post-GH-R signaling (e.g. STAT5 defects), IGFALS mutations and $I G F 1 R$ gene mutations or rearrangements.

Most reported IGF1R mutations were diagnosed in children born small for gestational age (SGA) (1). These mutations can affect ligand binding and/or reduce cellsurface IGF1R levels (1). With the exception of a small number of compound IGF1R heterozygous cases $(2,3)$, only heterozygous carriers have been reported in the literature $(4,5,6,7,8,9,10,11,12,13,14,15,16)$. Furthermore, only one single patient carrying homozygous mutations has been described so far (17). Given the lethality seen in IGF1R-null mice (18), a homozygous IGF1R defect in humans may not be compatible with life. These authors suggested that only hypomorphic IGF1R mutations in a homozygous state, as found in their patient, are compatible with life, whereas loss-of-function mutations affecting both $I G F 1 R$ alleles can be expected to be lethal.

Besides IGF1R mutations, terminal deletions of chromosomal region $15 \mathrm{q}$, encompassing the IGF1R locus, have been reported $(19,20)$. In addition to their effect on growth and development, these rearrangements often also exhibit other clinical features such as skeletal and cardiac abnormalities $(19,20)$. Most reported patients with an IGF1R defect manifest severe intrauterine growth retardation (IUGR) (1, 20), postnatal growth failure and microcephaly $(1,20,21)$. However, the resulting phenotypes are usually variable, presumably depending on the impact of the mutation on the function of the IGF1R.

We report here the identification of a new heterozygous missense mutation in exon 1 of IGF1R (D1105E) in three generations presenting with SGA, microcephaly and abnormal glucose metabolism. In vitro studies revealed that fibroblasts derived from the patient showed reduced proliferation and impaired IGF1R activation. Our data underline the key role of the IGF1R in the regulation of both growth and metabolic processes.

\section{Patients and methods}

\section{Index case and family members}

The index case was referred for endocrine evaluation at the age of 7 months due to episodes of hypoglycemia.
Blood samples were obtained from the patient's father, mother, maternal aunt and maternal grandmother. Height was determined with Harpenden stadiometer, and weight and head circumference were measured with standard equipment. Body mass index (BMI) was calculated by dividing the weight in kilograms by the square of the height in meters. Bone age was evaluated by the method of Greulich and Pyle (22). The study was approved by the Rabin Medical Center Ethics Committee, Israel, and the parents gave informed consent for the studies. Plasma GH was measured by a solid-phase two-site chemiluminescent immunometric assay (Immulite 2000; Siemens). Plasma IGF-1 was determined using a one-step sandwich chemiluminescence immunoassay (DiaSorin, Saluggia, Italy). Blood samples were collected for DNA extraction. Skin biopsies from the proband and his mother as well as age- and sex-matched controls provided skin fibroblasts for analysis.

\section{Sanger sequencing}

The determination of the IGF1R gene (ENST00000268035, NM_000875.3) mutation was performed on DNA extracted from whole blood and screened using forward and reverse primers (available upon request to the authors) flanking all 21 coding and splicing exons regions. Detection was done by Sanger sequencing, loaded on an ABI 16 capillary apparatus (23).

\section{Cell cultures and treatments}

The skin fibroblasts were grown in Chang Medium (BIOAMF-1 basal medium, Biological Industries Ltd., Beit HaEmek, Israel), supplemented with glutamine and antibiotics (penicillin/streptomycin/nystatin). Cells were treated with $50 \mathrm{ng} / \mathrm{mL}$ of IGF-1 (CytoLab, Rehovot, Israel). Stock concentration of IGF-1 was $1 \mathrm{mg} / \mathrm{mL}$.

\section{Real-time quantitative polymerase chain reactions (RQ-PCR)}

Total RNA was prepared from fibroblast cultures using TRIzol (Life Technologies). Single-stranded cDNA was synthesized from total RNA samples using the High-Capacity cDNA Reverse Transcription Kit (Applied Biosystems). IGF1R mRNA levels were measured by RQ-PCR, using the following primers: sense 5'-GAAGTGGAACCCTCCCTCTC-3'; antisense

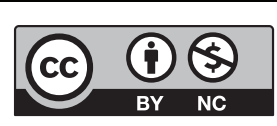

This work is licensed under a Creative Commons Attribution-NonCommercial 4.0 International License. 


\section{5'-CTTCTCGGCTTCAGTTTTGG-3'. Expression was} corrected to tubulin levels.

\section{Western immunoblots}

Cells were washed with ice-cold phosphate-buffered saline containing $5 \mathrm{mM}$ EDTA and lysed in a buffer composed of $150 \mathrm{mM} \mathrm{NaCl}, 20 \mathrm{mM}$ Hepes, $\mathrm{pH} 7.5,1 \%$ Triton $\mathrm{X}-100,2 \mathrm{mM}$ EDTA, $2 \mathrm{mM}$ EGTA, $1 \mathrm{mM}$ PMSF, $2 \mu \mathrm{g} / \mathrm{mL}$ aprotinin, $1 \mathrm{mM}$ leupeptin, $1 \mathrm{mM}$ pyrophosphate, $1 \mathrm{mM}$ vanadate and $1 \mathrm{mM}$ DTT. Protein extracts $(50 \mu \mathrm{g}$ protein) were subjected to $10 \%$ SDS-PAGE and transferred to nitrocellulose membranes. Membranes were blocked with 5\% non-fat milk in T-TBS $(20 \mathrm{mM}$ Tris-HCl, pH 7.5, $135 \mathrm{mM} \mathrm{NaCl}$ and $0.1 \%$ Tween20) and then incubated with antibodies against total- and phospho-IGF1R (\# SC-3027 and SC-3024, Santa Cruz Biotechnology), total- and phospho-ERK (\# SC-9102 and SC-9106, Santa Cruz Biotechnology) and total- and phospho-AKT (\# SC-9272 and SC-9271, Santa Cruz Biotechnology). Proteins were detected using the SuperSignal West Pico chemiluminescent substrate (Pierce).

\section{XTT cell proliferation assay}

Cell proliferation was monitored using an XTT cell proliferation kit (Biological Industries Ltd) according to the manufacturer's instructions. Fibroblasts were seeded at a density of 7000 cells/well in 96-well plates. Proliferation rate was measured $24 \mathrm{~h}$ following seeding.

\section{Statistical analyses}

The statistical significance of differences between groups in proliferation assays was assessed by the Student's $t$-test (two samples, equal variance). $P$ values $<0.05$ were considered statistically significant.

\section{Results}

\section{Clinical presentation of the patient}

The patient was born at 36 weeks of gestation as the second child of non-consanguineous parents of Ashkenazi Jewish origin (Fig. 1). His birth weight was 1875 g (-2.5 SDS); birth length was not documented. At 7 months of age, he was referred for endocrine evaluation due to episodes of hypoglycemia. He had a documented episode of (c) 2017 The authors

http://www.endocrineconnections.org DOI: 10.1530/EC-17-0038
I

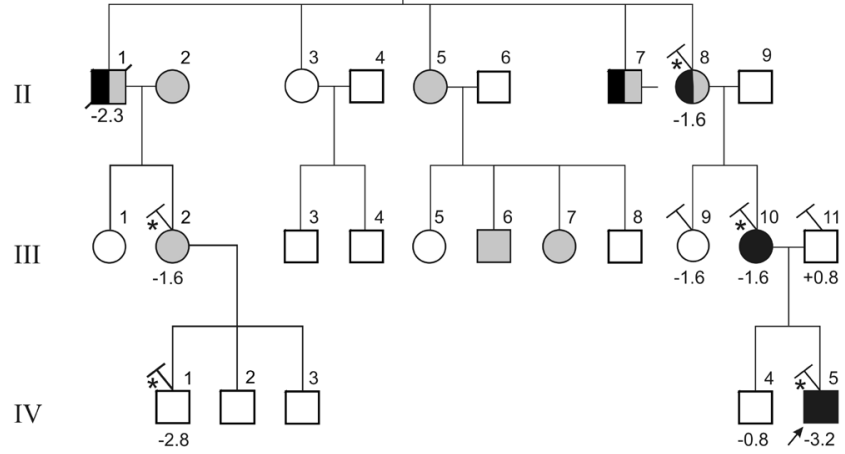

Figure 1

Pedigree of the index patient's (arrow) family and known relatives. Gray symbols indicate subjects with diagnosed type 2 diabetes mellitus; black symbols mark individuals with present or past hypoglycemia. Below the symbols, height SDS is given. Rods - subjects for whom genetic analyses of the IGF1R were performed. Individuals carrying the heterozygous c. $94+1 g>$ a IGF1R mutation are indicated by asterisks (*).

hypoglycemia on the second day of life, with no further episodes at the neonatal care unit. The patient suffered from severe gastro-esophageal reflux and poor appetite due to delayed gastric emptying. At 7 months of age, during an episode of continuous vomiting, he had documented hypoglycemia of $31 \mathrm{mg} \%(1.7 \mathrm{mmol} / \mathrm{L})$. When admitted, his weight was $4.59 \mathrm{~kg}$ (-4.9 SDS), length was $60.5 \mathrm{~cm}$ (-3.2 SDS), head circumference was $41 \mathrm{~cm}(-2.5$ SDS) and bone age that of a newborn. Clinodactyly, micrognathia and high-arched palate were also detected. His overall developmental milestones have been appropriate, his school performance (at age 9 years) is excellent and he participates in a program for gifted children.

The metabolic profile, including liver function tests, ammonia, lactate, pyruvate, free fatty acids, acetoacetate and beta-hydroxybutyrate, was normal. Samples drawn during several episodes of hypoglycemia showed undetectable levels of insulin and low C-peptide levels. Peak ACTH-stimulated cortisol was $795 \mathrm{nmol} / \mathrm{L}$ (normal $\geq 500 \mathrm{nmol} / \mathrm{L}$ ). The patient and his parents do not carry either of the 2 ABCC mutations commonly associated with hyperinsulinism of infancy in Ashkenazi Jews (24). Basal IGF-1 levels were within the normal range for age: 64 and $72 \mathrm{ng} / \mathrm{mL}$ (range 33-102). However, arginine- or glucagon-stimulated $\mathrm{GH}$ concentrations were subnormal: $4.1 \mathrm{ng} / \mathrm{mL}$ and $7.6 \mathrm{ng} / \mathrm{mL}$, respectively $(\geq 10.0 \mathrm{ng} / \mathrm{mL}$ considered a normal response).

Brain MRI revealed normal morphology of hypothalamus, stalk and hypophysis. Treatment with recombinant human GH (rhGH, 50 $\mu \mathrm{g} / \mathrm{kg} / \mathrm{day})$ was

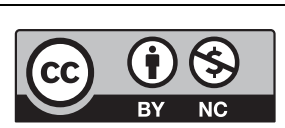

This work is licensed under a Creative Commons Attribution-NonCommercial 4.0 International License. 


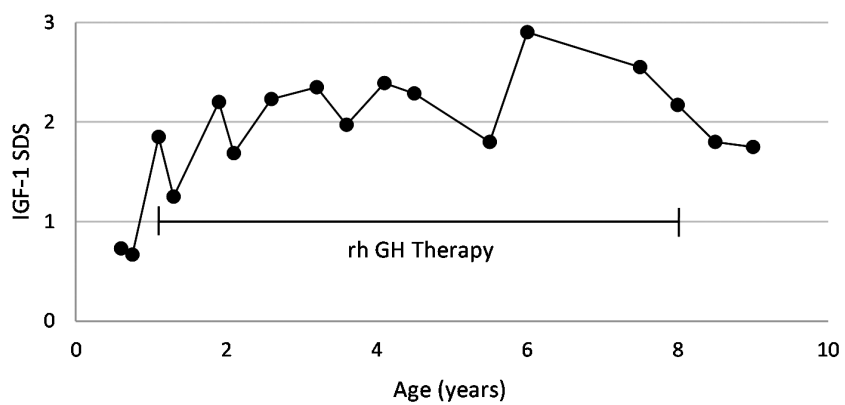

Figure 2

Serum IGF-1 levels of the index case, expressed as SDS for age and gender.

initiated at 1 year of age, increasing the length-SDS from -3.2 to -2.1 SDS after 1 year and to -1.5 after 2 years. His current height - SDS is -0.65 , and the upper/lower ratio is 1.01. Medical concern following diagnosis of colonic polyps led to discontinuation of GH therapy at 8 years of age. IGF-1 was increased during therapy, with values ranging from +1.5 to +2.4 SDS for age and gender and remained increased at +1.97 SDS while off therapy (Fig. 2).

Following the hypoglycemic episode at 7 months of age, there were no clinical or documented hypoglycemic events until 2 years of age, when symptomatic hypoglycemic events, both fasting and postprandial, occurred. Hypoglycemic episodes occurred almost every day and were not necessarily related to vomiting or intercurrent illness, although they were more frequent when intervals between meals were longer. Glucose levels ranged between 19 and $60 \mathrm{mg} \%$, as documented by glucose meter, laboratory analysis on several occasions and by the continuous glucose monitoring system. Fast tests performed twice added no further information. The hypoglycemic events occurred day and night and persisted despite frequent feedings with carbohydrateenriched meals and Proglycem (diazoxide) treatment.

A percutaneous feeding gastrostomy was also inserted as the gastro-esophageal reflux was associated with daily vomiting leading to hypoglycemic episodes and poor weight gain. The hypoglycemic episodes lessened significantly following insertion of a feeding gastrostomy as well as installation of a continuous glucose monitoring device, which by warning of a potential low glucose event can prevent or reduce the severity of hypoglycemia. Cessation of GH treatment notably had no effect on the hypoglycemic episodes.

Rectal bleeding at the age of 7.5 years was associated with benign polyps at the terminal ileum and at the cecum, showing normal mucosa and lymphoid hyperplasia on histopathology. Clinical characteristics of the three affected family members are shown in Table 1.

The patient's mother was born with a birth weight of $1100 \mathrm{~g}(-4.3 \mathrm{SDS})$ at 40 weeks of gestation. Her menarche occurred at 14 years of age. A hypoglycemic episode was first documented at the age of 18 years, but she recalled having had similar episodes during childhood. The onset of hypoglycemic events was not associated with change of eating habits, physical activity or any medications. Upon her first visit to our clinic with the patient, the mother was 32 years of age with a height of $154 \mathrm{~cm}(-1.6$ SDS), BMI $18.6 \mathrm{~kg} / \mathrm{m}^{2}$ and head circumference of $49 \mathrm{~cm}$ ( -5.0 SDS). The mother is a bright woman who graduated from law school. She reported excision of two benign colonic polyps diagnosed following rectal bleeding.

The mother presented with normal peak ACTHstimulated cortisol, thyroid function and normal anterior hypophysis hormones (prolactin, TSH, LH, FSH). An oral glucose tolerance test revealed normal glucose tolerance with a relatively high insulin and C-peptide response (Table 2). Serum IGF-1 levels were elevated in two of three samples drawn on different occasions. The mother still suffers from hypoglycemic episodes, as documented during a recent hospitalization and by a continuous glucose monitoring system. The glucose meter showed levels as low as $44 \mathrm{mg} \%$, verified by laboratory analysis. Two hours after fast test initiation hypoglycemia of

Table 1 Clinical characteristics of the affected patients with a heterozygous IGF1R mutation.

Age
Gender
Birth weight (g) (SDS)
Height at evaluation
Current head circumference (cm)
Current BMI (kg/m²)
Hypoglycemic events
Peak cortisol (nmol/L)
Co-morbidities
Neurocognitive function

\begin{tabular}{l}
\hline Index case \\
\hline 9 \\
Male \\
$1875(-2.5)$ \\
$60.5(-3.2)$ \\
$49(-2.6)$ \\
$14.3(-1.15)$ \\
Documented \\
795 \\
Colonic polyps \\
Normal
\end{tabular}

\begin{tabular}{l} 
Mother \\
\hline 40 \\
Female \\
$1100(-6.4)$ \\
$154(-1.6)$ \\
$49(-5.0)$ \\
$18.6(-1.9)$ \\
Documented \\
596 \\
Colonic polyps \\
Normal
\end{tabular}

Grandmother 71

Female

NA

$154(-1.6)$

$49(-5.0)$

$25.7(0.8)$

Reported

NA

None Normal http://www.endocrineconnections.org DOI: 10.1530/EC-17-0038
(C) 2017 The authors Published by Bioscientifica Ltd
This work is licensed under a Creative Commons Attribution-NonCommercial 4.0 International License. 
Table 2 Biochemical evaluation of the mother with a heterozygous IGF1R mutation.

\begin{tabular}{|c|c|c|c|c|c|c|}
\hline & Glucose & C-peptide (pmol/L) & Insulin (pmol/L) & $\mathbf{G H}(\mathrm{ng} / \mathrm{mL})$ & IGF-1 (ng/mL) & HbA1c \% (mmol/L) \\
\hline Normal range & & $0.3-2.4$ & & & $153-322$ & $4.2-5.7$ \\
\hline \multicolumn{7}{|c|}{ OGTT at 32 years } \\
\hline $0^{\prime}$ & 87 & 0.56 & 75 & & & $5.1(32)$ \\
\hline $1 \mathrm{~h}$ & 129 & 2.19 & 382 & & & \\
\hline $2 \mathrm{~h}$ & 105 & $>2.32$ & 451 & & & \\
\hline $3 \mathrm{~h}$ & 89 & 2.23 & 375 & & & \\
\hline \multicolumn{7}{|c|}{ OGTT at 37 years } \\
\hline $0^{\prime}$ & 81 & 0.36 & 41.5 & 8.63 & 270.4 & $5.4(36)$ \\
\hline $1 \mathrm{~h}$ & 153 & 2.38 & 345 & & & \\
\hline $2 \mathrm{~h}$ & 131 & 2.67 & 257 & & & \\
\hline \multicolumn{7}{|c|}{ Fast test at 40 years } \\
\hline $0^{\prime}$ & 64 & & & & & $5.1(32)$ \\
\hline $120^{\prime}$ & 31 & 0.37 & 40.1 & & & \\
\hline \multicolumn{7}{|c|}{ Random blood samples } \\
\hline At 33 years & 70 & 0.35 & 142 & 0.43 & 472.5 & \\
\hline At 39 years & 80 & & & 4.96 & 358.5 & \\
\hline
\end{tabular}

$31 \mathrm{mg} \%$ occurred, with insulin of $40.1 \mathrm{pmol} / \mathrm{L}$. Work-up for insulinoma, including imaging, was negative.

The father of the patient is healthy, $181 \mathrm{~cm}$ tall (+0.8 SDS), BMI $29.6 \mathrm{~kg} / \mathrm{m}^{2}$. The birth weight of the patient's brother was $2800 \mathrm{~g}$ and length, $51 \mathrm{~cm}$. His current height (at 13 years) is -0.8 SDS and weight -0.09 SDS.

SGA and relatively short stature were noted in several other maternal family members, including the maternal grandmother (Fig. 1, II 8). At age 71 years, her height was $154 \mathrm{~cm}(-1.6 \mathrm{SDS}), \mathrm{BMI} 25.4 \mathrm{~kg} / \mathrm{m}^{2}$ and head circumference $49 \mathrm{~cm}$ (-5.0 SDS). Menarche occurred at age 14.5 years. Episodes of weakness and tremor when she was younger had resolved following a sweet drink and may have resulted from hypoglycemia. At age 50 years, she was diagnosed with type 2 diabetes and is currently treated with insulin. Her mother and three of her siblings suffered from diabetes; two of them (II1, II7) are reported to have had hypoglycemic events at a young age. The clinical features of SGA, poor appetite and poor feeding, delayed gastric emptying, prominent forehead, clinodactyly and recurrent hypoglycemia could be compatible with RussellSilver syndrome (24). However, analysis for the common mutations of Russell-Silver was negative.

\section{Molecular analysis}

Molecular evaluation of the IGF1R gene revealed a novel heterozygous c. $94+1 \mathrm{~g}>$, a mutation affecting splicing of the mRNA. The mother and maternal grandmother are carriers of the same mutation. The maternal aunt and the unaffected father do not carry the mutation. The mutation was not found in large population databases, such as ExAC and ESP, or in 380 alleles in our internal database. (c) 2017 The authors Published by Bioscientifica Ltd
mRNA analysis showed that this sequence change causes an addition of four nucleotides at the end of exon 1 and, as a result, frameshift and truncation of the protein p.I32NfsX114. Owing to the location of the mutation at exon 1, using an in silico model of the mutated protein was impossible.

\section{Functional studies}

To evaluate the impact of the identified IGF1R mutation on IGF1R function, we isolated skin fibroblasts from the patient and his mother as well as from age/sex-matched control subjects. Primary fibroblast cultures were serum starved for $24 \mathrm{~h}$, after which they were treated with IGF-1 $(50 \mathrm{ng} / \mathrm{mL})$ for $10 \mathrm{~min}$. At the end of the incubation period, phosphorylation of the IGF-1R, extracellularsignal-regulated kinase 1/2 (ERK1/2) and protein kinase B/AKT were measured by Western immunoblotting. As expected, while addition of IGF-1 resulted in significant IGF1R phosphorylation in control cells (Fig. 3), IGF1R phosphorylation was absent in the patient's fibroblasts and was very low in protein extracts from the patient's mother. Lack of IGF1R phosphorylation may result from haploinsufficiency of the IGF1R gene or, alternatively, low sensitivity of the Western immunoblot with a specific phospho-IGF1R antibody. Likewise, IGF-1 induced phosphorylation of AKT in fibroblasts from the patient's mother and control, but not in the patient's fibroblasts. We found increased basal levels of phosphoERK in fibroblasts from the patient and his mother, but not in control cells. Addition of IGF-1 had no further effect on ERK phosphorylation in the patient cells, suggesting that the protein was already maximally activated under basal conditions. http://www.endocrineconnections.org DOI: 10.1530/EC-17-0038

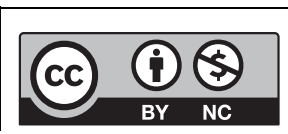

This work is licensed under a Creative Commons Attribution-NonCommercial 4.0 International License. 
pIGF1R

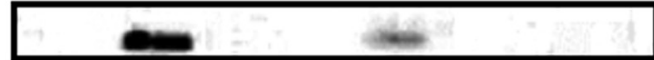

tIGF1R

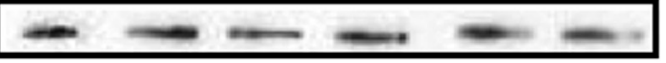

PAKT

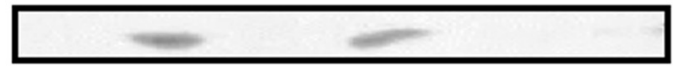

tAKT

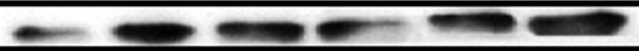

pERK

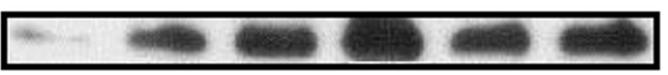

tERK

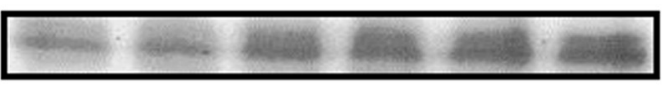

Tubulin

\section{IGF1}

$50 \mathrm{ng} / \mathrm{ml}$

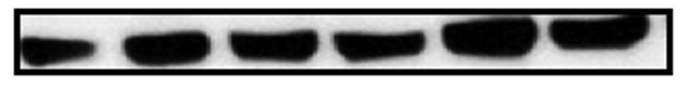

control

mother

Index case

Figure 3

Western blot analysis of IGF1R-mediated signaling in IGF1R-mutant patient and mother. Fibroblast cultures of proband, mother and control were serum-starved for $24 \mathrm{~h}$, after which they were treated with IGF-1 $(50 \mathrm{ng} / \mathrm{mL})$ for $10 \mathrm{~min}$. At the end of the incubation period, cells were lysed and electrophoresed through SDS-PAGE. Membranes were incubated with antibodies against total- and phospho-IGF1R, AKT and ERK. Tubulin levels were measured as a loading control.

\section{Proliferation assays}

To assess the impact of the IGF1R mutation on cell proliferation, XTT assays were used. Fibroblasts were grown in serum-containing media for $24 \mathrm{~h}$, after which proliferation tests were performed. As shown in Fig. 4, marked differences were seen between mother and proband and control cells. Specifically, the proliferation rate of the mother's cells was reduced by $60 \%$ compared to that of control cells, whereas that of the child was reduced by $40 \%(P<0.05)$. Similar reductions in proliferation rates of the cells of the patient and of the mother as compared to those of healthy fibroblasts were seen when using a $\mathrm{H}^{3}$-thymidine incorporation protocol (data not shown). Taken together, these data suggest a direct link between lack of IGF1R activation and impaired proliferation.

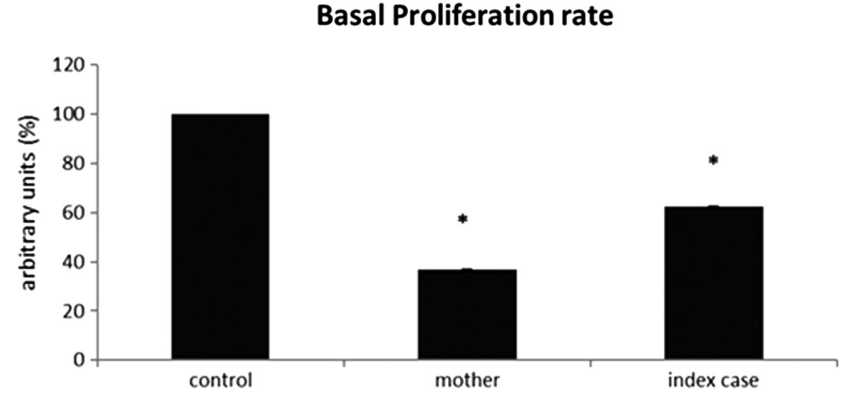

Figure 4

Proliferation assays fibroblasts of patient and mother. Fibroblasts were grown in serum-containing media for $24 \mathrm{~h}$, after which proliferation tests were performed using an XTT assay. Values on the $y$-axis represent arbitrary units of absorbance. A value of $100 \%$ was assigned to the number of cells in control cultures. The bars represent mean \pm S.E.M. of three independent experiments, performed each in triplicate samples. $* P<0.05$ vs control.

\section{Discussion}

We report the identification of a novel heterozygous IGF1R mutation (c. $94+1 \mathrm{~g}>\mathrm{a})$ in three microcephalic and relatively short-statured members of the same family, presenting with hypoglycemia early in life. The development of subsequent impaired glucose tolerance and diabetes later in life may be attributed to the same mutation. While most clinical features of the affected family members across three generations were similar to those of patients with IGF1R mutations previously described $(1,21)$, including SGA, microcephaly and relatively short stature, this is, to the best of our knowledge, the first report of an IGF1R gene mutation manifesting with hypoglycemia. Indeed, previously described IGF1R mutations were either associated with impaired glucose metabolism $(3,14,15,16,25,26)$ or had no effect on glucose metabolism $(2,5,6,7,9$, $10,12,13,20)$. To date, only one girl with a deletion on $15 \mathrm{q} 26.2$, resulting in a single $I G F 1 R$ gene copy, has been reported as having recurrent hypoglycemic episodes (26). The authors, however, could not explain the etiology of this condition. Hypoglycemia has not been reported in other patients with $15 \mathrm{q} 26.3$ deletion $(16,19,20)$.

Children who are hemizygous at the IGF1R locus usually show growth failure $(1,21)$, and some craniofacial abnormalities, including microcephaly, triangular facies, hypertelorism, high-arched palate, abnormal ears and micrognathia, as well as skeletal abnormalities including http://www.endocrineconnections.org
DOI: 10.1530/EC-17-0038

2017 The authors

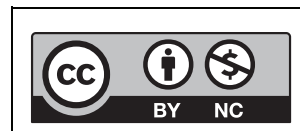

This work is licensed under a Creative Commons Attribution-NonCommercial 4.0 International License. 
clinodactyly, proximal placement of digits, club feet and scoliosis (21). The clinical features overlap to a large extent with Russell-Silver syndrome (27), although all those with deletions of 15 qter showed developmental delay and some degree of mental retardation (28), neither of which has been observed in children with Russell-Silver. In view of the clinical features associated with hypoglycemia in our index case, who is exceptionally bright, a diagnosis of Russell-Silver was initially suspected but not confirmed.

Hypoglycemic episodes occurred in the grandmother and two of her siblings in their twenties, in the mother during childhood and in our patient during infancy. This could constitute a typical case of genetic anticipation. Several mechanisms may have contributed to the hypoglycemic events. These mechanisms include the following: (1) Increased insulin sensitivity. Classical haploinsufficiency of IGF1R due to loss of about half the receptor concentration was shown to improve the insulin sensitivity in the patient's fibroblasts, as demonstrated by a quantitative increase of AKT activation in response to insulin (9). (2) The paucity of IGF-1 receptors could result in a high content of hybrid receptors, composed of one $\alpha \beta$ IGF1R hemireceptor linked to one $\alpha \beta$ insulin receptor hemireceptor. Hybrid receptors containing the IR-B isoform are expressed predominantly in muscle and adipose tissue (29), which are important target tissues for insulin action. A recent laboratory study suggested that binding of IGF-1 to this particular hybrid receptor may be as potent in stimulating glucose uptake as insulin binding to its cognate receptor (30). (3) Laboratory studies have shown that IGF-1 can promote glucose uptake in certain peripheral tissues (31). Although the magnitude of this effect is only $4-7 \%$ of that of insulin (32), the molar concentration of IGF-1 in human plasma is 100-fold greater than that of insulin. This difference in concentrations is further accentuated in our patients. (4) IGF-1 can suppress hepatic glucose production $(33,34,35)$. Despite a low number of receptors, high IGF-1 values may have a compensatory effect, leading to hypoglycemia. (5) The high IGF-1 levels may have suppressed GH and blunted its glycemic effect. This hypothesis is supported by the finding of subnormal GH levels in our patient, but should be questioned as GH therapy did not seem to ameliorate hypoglycemic episodes. (6) High circulating IGF-1 could bind to the insulin receptor, as insulin and IGF-1 are known to bind to each other's receptors (albeit with low affinity and, usually, at supra-physiological levels) $(36,37)$. The first two options, suggesting increased insulin sensitivity, are more likely, while the rest are associated with increased IGF-1 level, not found initially in our patient. The question which of these (or other) putative mechanisms led to hypoglycemia in our patient, and not in patients with other IGF1R mutations described to date, remains to be elucidated.

It is possible that the diabetes that developed later in life in the grandmother, who carries the mutation, and in at least two of her brothers might be associated with the mutation. The evolution of the disorder from hypoglycemia to overt diabetes is very complex, and the pathogenic mechanism may involve both $\beta$-cell exhaustion and apoptosis. There is some genetic evidence for a role of IGF-1 in glucose metabolism. In particular, a rare state of IGF-1 deficiency related to a homozygous partial deletion in the IGFI gene (IGF1) has been associated with severe insulin resistance, which was normalized by IGF-1 therapy (38). IGF-1 resistance due to the mutation could block this effect and induce insulin resistance, which over a long period of time may lead to $\beta$-cell exhaustion. $\beta$-cells express the IGF1R, and the tyrosine kinase activity of these receptors could potentially alter insulin secretion by influencing cell replication and survival $(39,40)$. Moreover, as IGF-1 has a positive antiapoptotic effect (41), resistance may contribute to $\beta$-cell apoptosis. Furthermore, as insulin resistance worsens and insulin levels rise, these higher insulin levels result in lower serum IGFBP-1 levels, upregulation of hepatic IGF-1 production and higher levels of free (presumably, bioactive) IGF-1 levels.

The subnormal response of $\mathrm{GH}$ to stimulation in the index case may represent transient GH deficiency rather than true deficiency. It is well recognized, based on multiple studies that in the majority of patients diagnosed as idiopathic GH deficiency, this proves to be transient when re-evaluated at final height. This is especially true in partial GH deficiency, as was the case in our patient. As other pituitary hormonal axes were intact, brain MRI normal and stimulated GH consistent with partial GH deficiency (peak GH $7.6 \mathrm{ng} / \mathrm{mL}$ ), this may be a case of transient GH deficiency. At one year of age, when he presented with hypoglycemia, GH response was subnormal and length was $-3.3 \mathrm{SD}$ and therapy was clinically required. Growth significantly improved following therapy initiation. However, it is impossible to determine if it was GH effect or simply catch-up growth of an SGA infant. Hypoglycemic episodes were not affected by GH therapy or its cessation, indicating that its role in the pathogenesis of hypoglycemia, if at all, was minor. 


\section{Conclusion}

We report on a new heterozygous missense mutation in exon 1 of $I G F 1 R$ in three generations presenting with SGA, microcephaly and hypoglycemia. This mutation affects the splicing of the mRNA transcript, leading to addition of four nucleotides at the end of exon 1 . The net result of this frameshift mutation is a truncation of the receptor protein. It is reasonable to assume that this genetic lesion leads to a reduction in IGF1 binding. In turn, the mutation leads to decreased IGF1R phosphorylation and variable downstream response. Furthermore, IGF1R mutation was associated with a decreased proliferation rate. The molecular and biochemical events leading to hypoglycemia are yet to be elucidated.

\section{Declaration of interest}

The authors declare that there is no conflict of interest that could be perceived as prejudicing the impartiality of the research reported.

\section{Funding}

This work did not receive any specific grant from any funding agency in the public, commercial or not-for-profit sector

\section{Authors' contribution statement}

All authors contributed to the conception of the work, and the acquisition, analysis and interpretation of the data and drafting and revision of the manuscript. All authors meet the International Committee of Medical Journal Editors criteria for authorship for this manuscript, take responsibility for the integrity of the work as a whole and have given final approval to the version to be published.

\section{Acknowledgement}

The authors thank Ruth Fradkin for her editorial assistance.

\section{References}

1 Klammt J, Kiess W \& Pfäffle R. IGF1R mutations as cause of SGA. Best Practice and Research: Clinical Endocrinology and Metabolism 201125 191-206. (doi:10.1016/j.beem.2010.09.012)

2 Abuzzahab MJ, Schneider A, Goddard A, Grigorescu F, Lautier C, Keller E, Kiess W, Klammt J, Kratzsch J, Osgood D, et al. IGF-I receptor mutations resulting in intrauterine and postnatal growth retardation. New England Journal of Medicine 2003349 2211-2222. (doi:10.1056/ NEJMoa010107)

3 Fang P, Cho YH, Derr MA, Rosenfeld RG, Hwa V \& Cowell CT. Severe short stature caused by novel compound heterozygous mutations of the insulin-like growth factor 1 receptor (IGF1R). Journal of Clinical Endocrinology and Metabolism 201297 E243-E247. (doi:10.1210/ jc.2011-2142)

4 Harmel EM, Binder G, Barnikol-Oettler A, Caliebe J, Kiess W, Losekoot M, Ranke MB, Rappold GA, Schlicke M, Stobbe H, et al. Alu-mediated recombination defect in IGF1R: haploinsufficiency in a patient with short stature. Hormone Research in Paediatrics 201380 431-442. (doi:10.1159/000355410)

5 Leal AC, Montenegro LR, Saito RF, Ribeiro TC, Coutinho DC, Mendonca BB, Arnhold IJ \& Jorge AA. Analysis of the insulin-like growth factor 1 receptor gene in children born small for gestational age: in vitro characterization of a novel mutation (p.Arg511Trp) Clinical Endocrinology 201378 558-563. (doi:10.1111/cen.12048)

6 Fang P, Schwartz ID, Johnson BD, Derr MA, Roberts CT Jr, Hwa V \& Rosenfeld RG. Familial short stature caused by haploinsufficiency of the insulin-like growth factor I receptor due to nonsensemediated messenger ribonucleic acid decay. Journal of Clinical Endocrinology and Metabolism 200994 1740-1747. (doi:10.1210/jc.2008-1903)

7 Kawashima Y, Hakuno F, Okada S, Hotsubo T, Kinoshita T, Fujimoto M, Nishimura R, Fukushima T, Hanaki K, Takahashi S, et al. Familial short stature is associated with a novel dominant-negative heterozygous insulin-like growth factor 1 receptor (IGF1R) mutation. Clinical Endocrinology 201481 312-314. (doi:10.1111/cen.12317)

8 Wallborn T, Wüller S, Klammt J, Kruis T, Kratzsch J, Schmidt G, Schlicke M, Müller E, van de Leur HS, Kiess W, et al. A heterozygous mutation of the insulin-like growth factor-I receptor causes retention of the nascent protein in the endoplasmic reticulum and results in intrauterine and postnatal growth retardation. Journal of Clinical Endocrinology and Metabolism 201095 2316-2324. (doi:10.1210/jc.2009-2404)

9 Raile K, Klammt J, Schneider A, Keller A, Laue S, Smith R, Pfäffle R, Kratzsch J, Keller E \& Kiess W. Clinical and functional characteristics of the human Arg59Ter insulin-like growth factor 1 receptor (IGF1R) mutation: implications for a gene dosage effect of the human IGF1R. Journal of Clinical Endocrinology and Metabolism $2006912264-2271$. (doi:10.1210/jc.2005-2146)

10 Kruis T, Klammt J, Galli-Tsinopoulou A, Wallborn T, Schlicke M, Müller E, Kratzsch J, Körner A, Odeh R, Kiess W, et al. Heterozygous mutation within a kinase-conserved motif of the insulin-like growth factor I receptor causes intrauterine and postnatal growth retardation. Journal of Clinical Endocrinology and Metabolism 201095 1137-1142. (doi:10.1210/jc.2009-1433)

11 Inagaki K, Tiulpakov A, Rubtsov P, Sverdlova P, Peterkova V, Yakar S, Terekhov S \& LeRoith D. A familial insulin-like growth factor-I receptor mutant leads to short stature: clinical and biochemical characterization. Journal of Clinical Endocrinology and Metabolism 2007 92 1542-1548. (doi:10.1210/jc.2006-2354)

12 Labarta JI, Barrio E, Audí L, Fernández-Cancio M, Andaluz P, de Arriba A Puga B, Calvo MT, Mayayo E, Carrascosa A, et al. Familial short stature and intrauterine growth retardation associated with a novel mutation in the IGF-I receptor (IGF1R) gene. Clinical Endocrinology 201378 255-262. (doi:10.1111/j.1365-2265.2012.04481.x)

13 Kawashima Y, Kanzaki S, Yang F, Kinoshita T, Hanaki K, Nagaishi J, Ohtsuka Y, Hisatome I, Ninomoya H, Nanba E, et al. Mutation at cleavage site of insulin-like growth factor receptor in a short-stature child born with intrauterine growth retardation. Journal of Clinical Endocrinology and Metabolism 200590 4679-4687. (doi:10.1210/jc.2004-1947)

14 Burkhardt S, Gesing J, Kapellen TM, Kovacs P, Kratzsch J, Schlicke M, Stobbe H, Tönjes A, Klammt J \& Pfäffle R. Novel heterozygous IGF1R mutation in two brothers with developing impaired glucose tolerance. Journal of Pediatric Endocrinology and Metabolism 201528 217-225. (doi:10.1515/jpem-2014-0132)

15 Prontera P, Micale L, Verrotti A, Napolioni V, Stangoni G \& Merla G. A new homozygous IGF1R variant defines a clinically recognizable incomplete dominant form of SHORT syndrome. Human Mutation 201536 1043-1047. (doi:10.1002/humu.22853)

16 Walenkamp MJ, van der Kamp HJ, Pereira AM, Kant SG, van Duyvenvoorde HA, Kruithof MF, Breuning MH, Romijn JA, Karperien M \& Wit JM. A variable degree of intrauterine and postnatal growth retardation in a family with a missense mutation in the insulin-like growth factor I receptor. Journal of Clinical Endocrinology and Metabolism 200691 3062-3070. (doi:10.1210/jc.2005-1597)

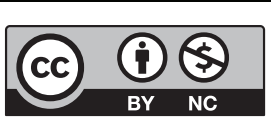


17 Gannagé-Yared MH, Klammt J, Chouery E, Corbani S, Mégarbané H, AbouGhoch J, Choucair N, Pfäffle R \& Mégarbané A. Homozygous mutation of the IGF1 receptor gene in a patient with severe pre- and postnatal growth failure and congenital malformations. European Journal of Endocrinology 2012168 K1-K7. (doi:10.1530/EJE-12-0701)

18 Liu JP, Baker J, Perkins AS, Robertson EJ \& Efstratiadis A. Mice carrying null mutations of the genes encoding insulin-like growth factor I (Igf-1) and type 1 IGF receptor (Igf1r). Cell 199375 59-72.

19 Davidsson J, Collin A, Björkhem G \& Soller M. Array based characterization of a terminal deletion involving chromosome subband 15q26.2: an emerging syndrome associated with growth retardation, cardiac defects and developmental delay. BMC Medical Genetics 20089 1-8. (doi:10.1186/1471-2350-9-2)

20 Ester WA, van Duyvenvoorde HA, de Wit CC, Broekman AJ, Ruivenkamp CA, Govaerts LC, Wit JM, Hokken-Koelega AC \& Losekoot M. Two short children born small for gestational age with insulin-like growth factor 1 receptor haploinsufficiency illustrate the heterogeneity of its phenotype. Journal of Clinical Endocrinology and Metabolism 200994 4717-4727. (doi:10.1210/jc.2008-1502)

21 David A, Hwa V, Metherell LA, Netchine I, Camacho-Hübner C, Clark AJ, Rosenfeld RG \& Savage MO. Evidence for a continuum of genetic, phenotypic, and biochemical abnormalities in children with growth hormone insensitivity. Endocrine Reviews 201132 472-497. (doi:10.1210/er.2010-0023)

22 Greulich WW \& Pyle SI. In Radiographic Atlas of the Skeletal Development of the Hand and Wrist, edn 2. Stanford, CA, USA: Stanford University Press, 1959

23 Bercovich D \& Beaudet AL. UBE3A mutation analysis by DHPLC. Genetics Testing 20037 189-194. (doi:10.1089/109065703322537197)

24 Nestorowicz A, Wilson BA, Schoor KP, Inoue H, Glaser B, Landau H, Stanley CA, Thornton PS, Clement JP 4th, Bryan J, et al. Mutations in the sulonylurea receptor gene are associated with familial hyperinsulinism in Ashkenazi Jews. Human Molecular Genetics 19965 1813-1822. (doi:10.1093/hmg/5.11.1813)

25 Netchine I, Rossignol S, Dufourg MN, Azzi S, Rousseau A, Perin L, Houang M, Steunou V, Esteva B, Thibaud N, et al. 11p15 imprinting center region 1 loss of methylation is a common and specific cause of typical Russell-Silver syndrome: clinical scoring system and epigenetic-phenotypic correlations. Journal of Clinical Endocrinology and Metabolism 200792 3148-3154. (doi:10.1210/jc.2007-0354)

26 Mohn A, Marcovecchio ML, de Giorgis T, Pfaeffle R, Chiarelli F \& Kiess W. An insulin-like growth factor-I receptor defect associated with short stature and impaired carbohydrate homeostasis in an Italian pedigree. Hormone Research in Paediatrics 201176 136-143. (doi:10.1159/000324957)

27 Okubo Y, Siddle K, Firth H, O'Rahilly S, Wilson LC, Willatt L, Fukushima T, Takahashi S, Petry CJ, Saukkonen T, et al. Cell proliferation activities on skin fibroblasts from a short child with absence of one copy of the type 1 insulin-like growth factor receptor (IGF1R) gene and a tall child with three copies of the IGF1R gene. Journal of Clinical Endocrinology and Metabolism 200388 5981-5988. (doi:10.1210/jc.2002-021080)

28 Jain S, Golde DW, Bailey R \& Geffner ME. Insulin-like growth factor-I resistance. Endocrine Reviews 199819 625-646.
29 Mosthaf L, Grako K, Dull TJ, Coussens L, Ullrich A \& McClain DA Functionally distinct insulin receptors generated by tissue-specific alternative splicing. EMBO Journal 19909 2409-2413.

30 Modan-Moses D, Janicot M, McLenithan JC, Lane MD \& Casella SJ. Expression and function of insulin/insulin-like growth factor I hybrid receptors during differentiation of 3T3-L1 preadipocytes. Biochemical Journal 1998333 825-831. (doi:10.1042/bj3330825)

31 Russell-Jones DL, Bates AT, Umpleby AM, Hennessy TR, Bowes SB, Hopkins KD, Jackson N, Kelly J, Shojaee-Moradie F, Jones RH, et al. A comparison of the effects of IGF-I and insulin on glucose metabolism, fat metabolism and the cardiovascular system in normal human volunteers. European Journal of Clinical Investigation 199525 403-411. (doi:10.1111/j.1365-2362.1995.tb01721.x)

32 Guler HP, Zapf J \& Froesch ER. Short-term metabolic effects of recombinant human insulin-like growth factor I in healthy adults New England Journal of Medicine 1987317 137-140. (doi:10.1056/ NEJM198707163170303)

33 Jacob R, Barrett E, Plewe G, Fagin KD \& Sherwin RS. Acute effects of insulin-like growth factor I on glucose and amino acid metabolism in the awake fasted rat.Comparison with insulin. Journal of Clinical Investigation 198983 1717-1723. (doi:10.1172/JCI114072)

34 Moxley RT 3rd, Arner P, Moss A, Skottner A, Fox M, James D \& Livingston JN. Acute effects of insulin-like growth factor I and insulin on glucose metabolism in vivo. American Journal of Physiology 1990 259 E561-E567.

35 Pratipanawatr T, Pratipanawatr W, Rosen C, Berria R, Bajaj M, Cusi K, Mandarino L, Kashyap S, Belfort R \& DeFronzo RA. Effect of IGF-I on FFA and glucose metabolism in control and type 2 diabetic subjects. American Journal of Physiology: Endocrinology and Metabolism 2002282 E1360-E1368. (doi:10.1152/ajpendo.00335.2001)

36 Clemmons DR. Involvement of insulin-like growth factor-I in the control of glucose homeostasis. Current Opinion in Pharmacology 2006 6 620-625. (doi:10.1016/j.coph.2006.08.006)

37 Li G, Barrett EJ, Wang H, Chai W \& Liu Z. Insulin at physiological concentrations selectively activates insulin but not Insulin-like growth factor I (IGF-I) or Insulin/IGF-I hybrid receptors in endothelial cells. Endocrinology 2005146 4690-4696. (doi:10.1210/en.2005-0505)

38 Woods KA, Camacho-Hubner C, Bergman RN, Barter D, Clark AJ \& Savage MO. Effects of insulin-like growth factor I (IGF-I) therapy on body composition and insulin resistance in IGF-I gene deletion. Journal of Clinical Endocrinology and Metabolism 200085 1407-1411. (doi:10.1210/jcem.85.4.6495)

39 Jones PM \& Persaud SJ. Tyrosine kinase inhibitors inhibit glucosestimulated insulin secretion. Biochemical Society Transactions 1994 22 209S. (doi:10.1042/bst022209s)

40 Persaud SJ, Harris TE, Burns CJ \& Jones PM. Tyrosine kinases play a permissive role in glucose-induced insulin secretion from adult rat islets. Journal of Molecular Endocrinology 199922 19-28. (doi:10.1677/ jme.0.0220019)

41 Robertson K, Lu Y, De Jesus K, Li B, Su Q, Lund PK \& Liu JL. A general and islet cell-enriched overexpression of IGF-I results in normal islet cell growth, hypoglycemia, and significant resistance to experimental diabetes. American Journal of Physiology: Endocrinology and Metabolism 2008294 E928-E938. (doi:10.1152/ajpendo.00606.2007)
Received in final form 8 June 2017

Accepted 22 June 2017

Accepted Preprint published online 22 June 2017 http://www.endocrineconnections.org DOI: 10.1530/EC-17-0038
(C) 2017 The authors Published by Bioscientifica Ltd

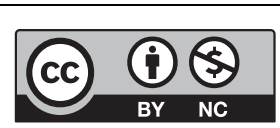

This work is licensed under a Creative Commons Attribution-NonCommercial 4.0 International License. 